\title{
O DRAMA MIDIÁTICO COMO DISCURSO DA VERDADE: SEDUÇÃO E AFETO PARA O CONSUMO DA INFORMAÇÃO SIMBÓLICA
}

\author{
Muniz Sodré de Araújo Cabral* \\ Ricardo Moraes ${ }^{* *}$
}

\begin{abstract}
Resumo: O presente artigo tem como objetivo investigar o discurso simbólico pelo viés do drama midiático como uma teatralização apropriada pelos canais de comunicação, nos quais o recurso da imagem é bastante utilizado assemelhando-se à pictoriedade da cena teatral. Tal teatralização foge aos recursos essenciais da comunicação teatral, o que nos leva a crer numa grande participação de interesses no desvio desse discurso que termina por se tornar universalizante e um forte componente midiático do senso comum dos ordenamentos, relações e organizações sociais.
\end{abstract}

Palavras-chave: Mídia. Comunicação. Drama. Teatralização. Discurso simbólico.

Recordando o movimento do Romantismo, encontramos o Estado-Nação que ao longo do desenvolvimento social, mediante suas relações com o povo, tornou-se este a própria nação que conferia a ele mesmo o poder construído pelas relações sociais, edificando, então, poderes pulverizados, gerando através dessas teias de interações ou redes de comunicação as representações.

Percebe-se que as representações podem ser de caráter expressivo; de forma que cabe a questão: elas expressam o social ou constituem o social? Além disso, podem ser também indiciárias de construções identitárias ou relações sociais? Acreditamos que estas, sim, constituem o social.

Quando falamos em representação é preciso ter em mente que o ato de representar é apresentar novamente, e segundo Saussure (1995) isso não se dá mais pela fala - que é individual - mas sim pelas regras de linguagem que se tornaram universais.

Foucault (2004) diz que a língua está sempre ligada a uma prática social individual que pode ser tomada como uma ação individual que provoca um sentido único, ou seja, uma representação dentro de um contexto de acordo com o tempo ou a época. É preciso contextualizar essas representações para se tornarem críveis.

O processo de representação apresenta um mundo que não é o real, e sim um imaginário da realidade forjado ideologicamente, e também, porque não dizer, coercitivamente pela esfera dominante. Na representação imaginária do mundo que se encontra em uma ideologia predominante estão refletidas as condições de existência dos

\footnotetext{
* Doutor em Letras pela UFRJ/ECO. Professor Titular (Emérito) da Escola de Comunicação da UFRJ/ECO. E-mail: sodremuniz@hotmail.com.

** Doutorando em Comunicação e Cultura pelo PPGCOM, UFRJ/ECO. Professor do Instituto Superior CAL de Arte e Cultura. E-mail: ricomoraes@gmail.com.
} 
homens, e, portanto, seu mundo real, ou seja, esse mundo forjado em que vivem passa a ser o real. Existe uma forte e influenciável relação entre os homens e as suas condições de existência. Esse arrolamento é o ponto central de toda representação ideológica, e, por conseguinte, imaginária do mundo real. Nessa interação está contida a causa que deve dar conta da deformação imaginária da representação ideológica do mundo real (ALTHUSSER, 1998).

Ao falar sobre o Drama Midiático, expressão calcada em outro olhar para a produção de conteúdo dos aparelhos comunicacionais, é necessário nos reportar ao drama em sua intenção idônea relacionada à sociedade.

Quando pensamos em drama no senso comum muitas vezes nos rebate no pensamento um discorrer de um momento da vida, ou seja, "fulano passa por um grande drama em sua vida", muitas dessas vezes essas são as chamadas das reportagens "teatralizadas" vinculadas em nosso meio comunicacional, principalmente o audiovisual, atingindo e estimulando o indivíduo à outra percepção da realidade, esta construída pela mídia. De acordo com Mattelart (1999), ao utilizar Harold Lasswell:

\begin{abstract}
Os meios de comunicação apareceram como instrumentos indispensáveis para gestão governamental das opiniões. Segundo Lasswell, a propaganda entra em consonância com a democracia, tornando-se o único meio de suscitar a adesão das massas, e - mais econômica que a violência, a corrupção e outras técnicas de governo desse gênero. A audiência é vista como um alvo amorfo que obedece cegamente ao esquema estímulo-resposta, ou seja, é pensado como um modelo de 'agulha hipodérmica', termo criado por Lasswell para designar os impactos direto e indiferenciado sobre o indivíduo (MATTELART, 1999, p. 48).
\end{abstract}

O Drama em sua essência humana é a linha de vida ${ }^{2}$ de uma sociedade ou um indivíduo, e não somente um momento. Quando o Teatro Grego mostra o Drama de sua sociedade, expõe as relações dos mortais com os semideuses e com os deuses, e como tais relações formam, mantêm e procuram desenvolver o entendimento humano à sua população. Desse modo, o povo que ali habita e interage percebe mais profundamente tais relações como componente de uma formação de vida individual e social, justamente o que contempla uma sociedade em geral.

No teatro, a função do drama é mostrar com máxima verossimilhança a sociedade/espaço/ambiente em que convivem seus transeuntes, e com isso deixar a compreensão social, tal como propõe Max Weber (2009) em sua "sociologia compreensiva", mais aberta e palpável à população. Essa é, e sempre foi, não só a função, mas a intenção do teatro. Externa tal intento ao mostrar profunda e explicitamente através do drama de um indivíduo (Hamlet), de uma cidade (Tróia) ou de uma nação (Ricardo III) o que realmente ocorre no âmbito social e na psique humana.

Assim sendo, vale-se dos recursos da teatralização que englobam o modo como isso será apontado, dito, escrito, pintado, e em geral encenado, para, aí sim, se valer de

\footnotetext{
${ }^{1}$ Segundo este modelo, uma mensagem lançada pela mídia é imediatamente aceita e espalhada entre todos os receptores, em igual proporção.

${ }^{2}$ No teatro, chamada de linha contínua de ações das personagens que ao se entrelaçarem dão sentido à existência e à sociedade.
} 
momentos que comporão o todo do drama, tal qual Walter Benjamin (1996) propõe em seus estudos da arte e política ao analisar a história pela "tensão social" de um fato pinçando um momento significativo da história para, então, continuar transcorrendo discursivamente buscando a verdade do todo histórico. Por outro lado, a mídia utiliza esse afeto, identificação e sedução pelo identificável para outro modo de produzir verdades.

Os canais midiáticos com seus recursos imagéticos, textuais, "afetivos" (SODRÉ, 2006) produzem uma identificação que leva a uma "pertença" (GIDDENS, 2002) do indivíduo, o deixando mais receptivo às produções midiáticas do nosso cotidiano. "O animal humano 'se educa' à lidar com as relações, sejam elas diretas, indiretas, eletrônicas etc. $\mathrm{O}$ uso social da construção discursiva ou produtiva é que dará o sentido de realidade e verdade as coisas" (DUARTE; LOPES, 2015). Diferentemente da teatralização relacionada à encenação teatral que em sua intenção humana nos proporciona uma compreensão maior da sociedade, a mídia a utiliza se apropriando de seus recursos de produção dando a isso outro nome como o fetiche, por exemplo, que tem "uma significação através da parte pelo todo como o fetiche religioso que tem objetos de adoração e proteção como o seu símbolo de valor maior", assim como o "fetiche pornográfico, que apaga toda e qualquer existência amorosa de um humano para outro através do corpo, é o corpo pelo todo que vale como princípio de valor maior" (idem). E assim, conforme coloca Debord (1997), também é com as mercadorias e os seus valores simbólicos de troca, que passam longe da utilidade para um bem maior. A sua verdade é "apropriada" (LUKÁCS, 2009) e transformada em um vazio social do senso comum universal alienado.

Em vista do exposto sobre os comportamentos sociais que passam a ser internalizados pelos indivíduos, pode-se fazer uma conexão com o Habitus, de Bourdieu (2007b), onde se observa uma intervenção ideológica das trocas simbólicas no campo político e econômico, e também dos aparelhos midiáticos moldando comportamentos, modos de produção e relações sociais.

O Habitus a que se refere Bourdieu inicia-se a partir do conhecimento adquirido na família, na escola e no seguimento religioso, e, dessa forma, se edifica a distinção entre os grupos sociais direcionando determinados comportamentos e influências, principalmente midiáticas. Ainda, podem-se assinalar favorecidos e desfavorecidos, ou, se podemos dizer, os destacados no âmbito social e os indiferentes ou "desconectados" (CANCLINI, 2007). A tensão de tal sistema disciplinador gera a impossibilidade de sincera articulação e expressão da população.

Em meio a esse panorama, ressalta-se aqui a intenção deste artigo em mostrar, além da apropriação da teatralização feita pela mídia, proposições de subsídios para diferenciação entre a teatralização como parte de uma teatralidade dramática da vida, como "um curativo social" (JAEGER, 1995), e a teatralização midiática como parte de um esvaziamento discursivo através de imagens, textos, propagandas, telejornais, redes sociais, dentre outros.

Apresentam-se fatos apropriados pela hegemonia analisados com a perspectiva do mundo sensível: histórias verdadeiras de uma determinada comunidade ou sociedade - a grega, por exemplo -, que segundo Jaeger (1995) utilizava a estética cênica como uma 
verdadeira ação de comunicação comunitária mediante os acontecimentos sociais que enredavam as ações teatrais. A "dramatização dos principais problemas humanos unia atores (emissores) e espectadores (receptores) num intuito de compreensão dos fundamentos individuais, das necessidades psíquicas e sociais. Assim eram as danças primitivas, o teatro grego, os rituais religiosos" (KOSOVSKI, 2004).

Enfatizando o teatro grego: tratava-se de teatralizações com intuitos de reconhecimento do próprio indivíduo em meio ao campo social no qual se articulava e, principalmente, se desenvolvia para a vida em sociedade. A dramatização dos fatos tinha por objetivo o entendimento social e pretendia aflorar o sentimento de pertença de cada um, ou seja, saber qual peça da engrenagem social o sujeito, consciente de si, representa (JAEGER, 1995). Essa teatralização "engendra um conteúdo de conscientização e potencialização do sujeito no coletivo comunitário" (MORAES, 2011a, p. 4).

Sabendo que o sujeito não é pré-constituído, mas, sim, posicionado - pois ele nasce com determinada distinção, lugar, região, ou seja, em um mundo já constituído vale ressaltar a importância do conhecimento e cultura local, conforme o autor já citado, Jaeger (1995), coloca sobre a potencialidade da sociedade grega, e aproveitando-se os esclarecimentos de Clifford Geertz (2008/2009) e Homi Bhabha (1998) aliados ao pensamento a respeito das construções de identidade de Kwame Anthony Appiah (1997). Esses esclarecimentos e ideias são bastante significativos em relação à articulação, identificação e construção de caráter do sujeito individual e do corpo coletivo. Tais relações primam pela profundidade da verdade local em articulação com a global, não perdem os seus valores primordiais tão necessários ao desenvolvimento psíquico e social humano, prezando pelos atuantes da vida social.

É preciso "compreender a atuação como um ato teatral que transcende aspectos restritos ao teatro, perceber que emoções expressas, independente de sua geografia", no teatro ou na vida, "é servir-se de um campo perceptivo que auxilia-nos sobremaneira, para um entendimento do comportamento humano em variadas esferas constitutivas do tecido social assim como do afeto e da existência humana" (KOSOVSKI, 2002).

Por outro lado, há a discurso midiático, a que chamo aqui de "drama na mídia" ou "drama midiático", composto por "teatralizações midiáticas" que nos envolvem em uma camada sobreposta de sedução, afeto, sensibilidade e identificação, através das quais nos percebemos naturalmente envoltos numa redoma atrativa e satisfatória. Nela, participamos ativamente com a nossa "submissão subliminar" ou "consenso legitimador" (GRAMSCI, 2001) de nossas escolhas, tornando-as o que nos define enquanto sujeito e alterando o nosso fator comportamental, pois se sabe que "as empresas de comunicação são ancoradas no mercado do consumo de produtos e informações" (SODRÉ, 2002).

Os modos de produção dos discursos e as construções das relações são ancorados também pelo processo de linguagem. Com relação a este aspecto, o indivíduo interage e reage em meio ao "Illusio" - aceitação das normas das convenções que se dá nesse campo (DUARTE; LOPES, 2015). Para Mikhail Bakthin, ele é parte de uma "cadeia de interações verbais" (BAKTHIN, 2010) e atua em meio ao interdiscurso. O autor russo nos aponta que a linguagem comete as ligações das representações, e que estas são 
concretizadas por ações. Temos como exemplo ações de pessoas institucionais que dão o poder estrutural da passagem da linguagem ou discurso para ação, o que seria um ato eloquocionário de poder institucional como a prisão de João Vaccari Neto, tesoureiro do PT, em 15 de abril deste ano ${ }^{3}$, por exemplo. (DUARTE; LOPES, 2015).

Bakthin assinala que a ideologia ou pensamento universal está na interação do locutor e do receptor, não se encontra na consciência de nenhum dos dois. É necessário, por exemplo, conhecer o uso da arte e não somente a arte. Tal conhecimento se encontra na interação. E é nesta que os tentáculos da mídia agem por intermédio do "gerenciamento" colocado por Bakthin, ou seja, constroem discursos falsos utilizando fatos verdadeiros, e, na verdade, é o que mais os espaços midiáticos de longo alcance utilizam para transformar esses textos em discursos da verdade, conforme aponta Foucault (1979) ao se referir à universalização dos fatos como a verdade, o discurso construído pelas teias dos micropoderes como a verdade do senso comum, naturalizada. O autor coloca:

Afinal, somos julgados, condenados, classificados, obrigados a desempenhar tarefas e destinados a um certo modo de viver ou morrer em função dos discursos verdadeiros que trazem consigo efeitos específicos de poder. (FOUCAULT, 1979, p. 180).

Ainda sobre o assunto, o autor francês ressalta em seu livro $A$ ordem do discurso (2004) a importância da troca e da comunicação como figuras positivas no interior desses sistemas de restrição, e que não poderiam funcionar sem eles. O problema apresenta-se na superficialidade intrínseca destes sistemas. Essa superficialidade é chamada por Foucault de ritual. Pode-se aplicar esse ritual aos meios de comunicação como o jornalismo impresso e suas imposições à população "numa espécie de jogo jornalístico como, por exemplo, o 'entrevistado construído' ou a 'matéria construída'4 do jogo da mídia" (DUARTE; LOPES, 2015). Percebe-se nesse momento a linearidade jornalística, ou seja, o sujeito do tempo não é constituidor desse tempo, ele é submisso e se rende ao tempo e ao modo da informação. Como disse Eric Hobsbawn (1977; 1987),

\footnotetext{
3 Disponível em: <http://g1.globo.com/politica/operacao-lava-jato/noticia/2015/04/tesoureiro-do-pt-epreso-na-12-etapa- da-operacao-lava-jato.html $>$.

Disponível em: <http://www1.folha.uol.com.br/poder/2015/04/1616790-tesoureiro-do-pt-e-preso-pelapf.shtml>.

Disponívelem: $<$ http://www.ocafezinho.com/2015/07/11/a-outra-historia-por-tras-da-prisao-dotesoureiro-do-pt/>.

${ }^{4}$ Em uma reportagem exibida no Jornal Nacional, em maio de 2015, e depois disseminada nos sites de notícias, a condução da matéria mostrou Osama Bin Laden como um assíduo leitor de Noam Chomsky, o que seria improvável, apenas porque entre os muitos livros encontrados sob posse do líder islâmico existiam textos do autor e ativista político norte-americano.
}

Disponível em: <http://www.theguardian.com/world/2015/may/20/osama-bin-laden-library-noamchomsky-bob-woodward>.

Disponível em: <http://noticias.uol.com.br/internacional/ultimas-noticias/2015/05/20/biblioteca-e-binladen-continha-chomsky-e-teorias-da-conspiracao.htm>.

Disponível em: <http://observador.pt/2015/05/21/o-que-se-descobriu-na-casa-de-osama-bin-laden/ http://brasil.elpais.com/brasil/2015/05/20/internacional/1432140544_185485.html>. 
no século XVIII o homem do campo andava de sua fazenda até a paróquia e voltava, era um tempo circular que se restringia àquele espaço e sob o domínio do sujeito. Hoje o homem está para o mundo, porém, não é dono de seu tempo. Como outros exemplos, podem-se ver as gravadoras e grandes rádios sujeitas ao mercado fonográfico, a publicidade e seus meandros de ilusão propagandistas, e também, porque não ressaltar, o teatro e seus modos de produção elitizados e estetizantes que retiram do público popular a arte reflexiva e transformadora.

Em crítica, Foucault assinala que o ritual "define a qualificação que devem possuir os indivíduos que falam, define os gestos, os comportamentos, as circunstâncias, e todo o conjunto de signos que devem acompanhar o discurso", e mais, "fixa a eficácia suposta ou imposta das palavras, seu efeito sobre aqueles aos quais se dirigem os limites de seu valor de coerção" (2004, p. 39). O autor acredita que "um ritual determina para os sujeitos que falam, ao mesmo tempo, propriedades singulares e papéis preestabelecidos" (idem).

Aliando o aspecto ritualístico ao pensamento de Bakthin, enxerga-se na colocação do autor russo a "vida ritualizada" na qual estamos, nos portamos, interagimos da forma, como e com quem queremos, e no espaço/ambiente que desejamos, com gêneros específicos, e assim seguimos na "interação verbal" (BAKTHIN, 2010), levando a nossa vivência aonde for, criando novas interações.

Desse modo, alia-se a interação pela linguagem de Bakhtin ao comportamento disciplinar de Foucault, colocando em evidência sociológica e comunicacional a ação da mídia mediante conduções tão sutis a ponto de agradecermos com grande boa vontade e audiência toda e qualquer forma midiática de interação.

\section{A MÍDIA COMO MODERADOR DA VIDA SOCIAL: AFETO, SENSIBILIDADE E CONSUMO}

Peter Burke, autor de Uma História Social da Mídia, trabalha muito com a ideia da mídia como instrumento social. Enxergando a história da sociedade através da história da mídia, ou a mídia como reflexo da sociedade, Burke expôs em sua análise que gosta:

(...) sempre de falar, escrever e pensar "as mídias" no plural. Elas são meros reflexos da sociedade, pois têm muitas possibilidades de mudar a própria sociedade. É uma relação dialética (BURKE, 2006, p. 84).

Burke aponta os dois lados da moeda. É importante ressaltar que, mesmo com a influência maciça da mídia, ou das mídias, como diz o autor, há uma relação de aceitação não somente pelo consenso, pela sutileza subliminar, identificação individual ou coletiva, mas também pelo espelho, a mídia devolve o que a sociedade quer, tornando-se, então, um reflexo social. Há um atendimento da demanda do público por parte da mídia. Segue a colocação de Bourdieu sobre essa relação utilizando como exemplo a obra de arte quando fala a respeito do "campo das instâncias de reprodução e consagração": 
As obras produzidas pelo campo de produção erudita são obras "puras", "abstratas" e esotéricas. Obras "puras" porque exigem imperativamente do receptor um tipo de disposição adequado aos princípios de sua produção, a saber, uma disposição propriamente estética. Obras "abstratas", pois exigem enfoques específicos, ao contrário da arte indiferenciada das sociedades primitivas, e mobilizam em um espetáculo total e diretamente acessível todas as formas de expressão, desde a música e a dança, até o teatro e o canto. Por último, trata-se das obras esotéricas (...) por sua estrutura complexa que exige sempre a referência tácita à história inteira das estruturas anteriores. Por esse motivo, são acessíveis apenas aos detentores do manejo prático ou teórico de um código refinado (...), enquanto que a recepção dos produtos do sistema da indústria cultural é mais ou menos independente do nível de instrução dos receptores (uma vez que tal sistema tende a ajustar-se à demanda). (BOURDIEU, 2007a, p. 116-117).

Por isso, o historiador inglês assinala a importância dos reflexos sociais, que podem mudar a qualquer momento dentro de um processo de grande efemeridade. Há, também, uma legitimação mútua que alimenta ambos os lados, ou seja, é uma retro alimentação de produção de sentidos. Constatamos isso em uma série de transformações históricas da vida intelectual e artística colocadas por Bourdieu (2007a, p. 100), desde o período clássico, sendo as principais:

A constituição de um público de consumidores (...) cada vez mais extenso, socialmente mais diversificado, e capaz de propiciar aos produtores de bens simbólicos não somente as condições minimais de independência econômica, mas concedendo-lhes também um princípio de legitimação paralelo;

A constituição de um corpo cada vez mais numeroso e diferente de produtores e empresários de bens simbólicos cuja profissionalização faz com que passem a reconhecer exclusivamente um certo tipo de determinações como por exemplo os imperativos técnicos e as normas que definem as condições de acesso à profissão e de participação no meio;

A multiplicação e a diversificação das instâncias de consagração competindo pela legitimidade cultural (...).

Quando se trata de bens simbólicos e como fazem para persuadir sensivelmente as massas, faz-se necessário lançar criticamente outro olhar que englobe os recursos estratégicos da sensibilidade, afeto e identificação, sendo isso bastante vigente dentro da política intervencionista dos meios de comunicação.

Para Sodré (2006), as estratégias midiáticas de rápida absorção do público já deixaram de ser formadas por uma cultura de massa e passaram a ser forjadas socialmente pela cultura tecnológica, ou seja, pela "tecnocultura" e sua atomização não reflexiva, apenas sensitiva e emocional, tal qual aponto aqui em minha hipótese sobre a "teatralização midiática" e seus ensejos espontâneos dos fatos e ajustamentos de interesse para produção de informação, dependendo da instância e do momento. Muniz Sodré ainda assinala que:

As experiências sensíveis podem orientar-se por estratégias espontâneas de ajustamento e contato nas situações interativas, mas salvaguardando sempre para o indivíduo um olhar exterior aos atos puramente linguísticos, o lugar singularíssimo do afeto. (...). É verdade que as mídias e a propaganda têm mostrado como estratégias racionais não espontâneas 
podem instrumentalizar o sensível, manipulando os afetos. Na maioria das vezes, porém, tudo isso se passa em condições não apreensíveis pela consciência. Se já nas estratégias discursivas a consciência do sujeito não reina em termos absolutos sobre a sua posição de falante, muito menos comandam a consciência e a racionalidade calculadora no tocante à zona obscura e contingente dos afetos, matéria da estética considerada em sentido amplo, como modo de referir-se a toda a dimensão sensível da experiência vivida (SODRÉ, 2006, p. 11).

Sodré aponta o grande significado e importância das estratégias e táticas edificadas nas entrelinhas das produções discursivas e como elas se encontram referidas a jogos de guerra, de comércio, de política, de entretenimento ou de comunicação.

Pode-se enxergar nesse momento a capacidade de atuação - além da social cênica dos personagens reais envolvidos nos campos citados pelo autor. Encontra-se aí, com a intervenção da mídia, a teatralização midiática baseada em estratégias que evanescem com o real significado dos sentidos. O autor baiano expõe:

\begin{abstract}
São muitas as estratégias discursivas no jogo da comunicação. Cabe-lhes jogar, segundo as circunstâncias da situação interlocutória, com a forma inicial do sistema, visando à comunicação com um outro, como é bem o caso de uma estratégia de discurso, de discurso social para vulgarização de uma ciência. Mas uma linguagem ou um discurso, como se sabe, não se reduz a função de transmissão de conceitos referenciais. Na relação comunicativa, além da informação veiculada pelo enunciado, portanto, além do que se dá a conhecer, há o que se dá a reconhecer como relação entre duas subjetividades, entre os interlocutores (idem, p. 10).
\end{abstract}

Os dispositivos de comunicação precisam da audiência do espectador e por isso deve colocá-lo o mais próximo possível do fato contido na narrativa midiática. Há uma aproximação necessária para o envolvimento do espectador, mais do que isso, é imprescindível colocá-lo em cena, ele precisa sentir que o ocorrido poderia ser com ele.

Observa-se o jornalismo moderno ambientado nesse viés de introdução do espectador para maior receptividade. Uma notícia de crime, por exemplo, antes era narrada com ênfase no criminoso. De 1970 até os dias atuais, narra-se o sofrimento da vítima, da família, através da dramatização de testemunhos. Nesse caso, nota-se a vítima como uma "metonímia do público cansado e com medo" (VAZ, 2014). O agente direto 5 coloca em risco a vítima, ou seja, o inocente, enquanto o agente presumido ${ }^{6}$ que deveria proteger o inocente mostra-se envolto numa incompetência administrativa.

Enxerga-se nesse ponto a teatralização midiática formando "a causalidade construída pela notícia" (idem). O jornalista está cada vez mais inserido no "campo de batalha" de onde fala para o espectador, ou seja, o próprio material humano da informação é colocado "cenicamente", "estrategicamente", "sensivelmente", tal como faz um diretor teatral, no local da reportagem a intento não somente de transmitir essa realidade ao público, mas de colocá-lo como parte dessa realidade, seja ela trágica ou não. Isso ocorre através de imagens audiovisuais ou fotográficas como foi o caso da foto

\footnotetext{
${ }^{5}$ Traficantes, chuvas, desabamentos, terremotos, inundações.

${ }^{6}$ Quem poderia anteceder o acontecimento (aparelhos de repressão ou lei, como a polícia e o Estado) e conter o agente direto.
} 
publicada no jornal O Globo, em junho de 2008, em que mostra o pai segurando a mochila de colégio do seu filho, o qual havia perdido em uma epidemia de dengue no mesmo ano. Tal imagem pode ser ajustada $^{7}$ para ser registrada, ou registrada na espontaneidade $^{8}$, isso não invalida o conjunto de formação da teatralização midiática que irá compor o drama na mídia. Podem-se aglutinar tais ocorridos ao pensamento de Sodré (2006):

\begin{abstract}
Em termos práticos, a questão pode ser resumida assim: quem é para mim, esse outro com quem eu falo e vice-versa? Esta é a situação enunciativa, da qual não dão conta por inteiro a racionalidade linguística, nem as muitas lógicas argumentativas da comunicação. Aqui tem lugar o que nos permitimos chamar de estratégias sensiveis, para nos referirmos aos jogos de vinculação dos atos discursivos as relações de localização e afetação dos sujeitos no interior da linguagem (idem).
\end{abstract}

Tal como Muniz Sodré coloca em alta as questões das estratégias sensíveis, levantam-se aqui, ensejando o pensamento do autor, as mesmas medidas sutis utilizadas na teatralização do drama na mídia. Os afetos, o lugar das afectados e o modo como os variados públicos são abordados ou atingidos por essas medidas é que mostra a eficácia dessa produção comunicacional tão vigente em nosso tecido social. Soma-se aqui o apontamento de Sodré ao utilizar Eric Landowski, buscando integrá-lo ao cerne da estratégia comunicacional do drama na mídia analisado pelo viés da teatralização apropriada:

Landowski (...) persegue uma "semiótica do sensível", e situa-se teoricamente num "aquém e além das estratégias", ao conceber um regime comunicativo em que o sentido troca a lógica de circulação de valores do enunciado pela co-presença somática e sensorial dos actantes (LANDOWSKI, 2001 apud SODRÉ, 2006).

Fica claro o feito da teatralização cênica em sua essência por intermédio da sensorialidade. $\mathrm{O}$ afeto está na pele, é celular, provoca reações corpóreas e reflexivas a ponto de buscar uma transformação do indivíduo através de suas próprias ações. Há uma potencialidade da arte que busca o conhecimento e o reconhecimento do público, aí está a maior resposta de sua positividade, da sua função social enquanto movimento artístico transformador. Por outro lado, a teatralização midiática derrete essa função em uma camada homogênea de ilusão, ou seja, um ilusionismo que se move através da atomização e da não reflexão e nos leva a crer que tudo se desenvolve e se estrutura dentro de uma naturalidade aceita e legitimada pelo próprio receptor em sua resposta. Nota-se, por exemplo, a respeito da transformação da função e da significação da festa e da dança através dos tempos que:

Em Guipúzcoa, até o século XVIII, a dança, nos dias de festa, não era apenas um simples divertimento, mas uma função social de mais peso. O papel era quase tão importante como

\footnotetext{
7 À pedido da produção da reportagem, a foto é registrada mediante uma montagem cênica acordada anteriormente.

${ }^{8}$ Registrada no momento exato do desespero do(s) familiar(es), nesse caso.
} 
o dos atores. As ideias citadinas sobre a moda fizeram com que as pessoas das famílias importantes, os velhos, as pessoas casadas e os padres não assistissem mais aos bailes das praças, deixando de neles participar como antes, o baile, perdendo sua estatura coletiva, tornou-se o que é hoje um divertimento para os jovens onde o espectador não tem mais importância (BARCIA, 1964).

Tudo foi sensivelmente abarcado na psique do individuo ou do coletivo dependendo do interesse. Vemos que:

\begin{abstract}
(...) a dimensão da corporeidade nas experiências de contato direto, em que se vive, mais do que se interpreta semanticamente, o sentido: sentir implica o corpo, mais ainda, uma necessária conexão entre espírito e corpo. Ou então, a dimensão da imagem, em que o afeto e a tatilidade se sobrepõem à pura e simples circulação de conteúdos. Trata-se finalmente de reconhecer a potência emancipatória contida na ilusão, na emoção do riso e no sentimento da ironia, mas também na imaginação, requisito indispensável do "capital humano" compatível com as formas flexíveis do novo capitalismo (SODRÉ, 2006, p. 13).
\end{abstract}

Percebemos nas palavras de Sodré que há um caminho teórico que privilegia o emocional, o sentimental, o afeto, e ainda mais, o mítico, conforme Gilberto Freire abarca em seus estudos sobre a sociedade brasileira, quando inclui afetos, formas e até odores como análise de comportamento. "Dentro do movimento de fusão progressiva da vida com a tecnologia, torna-se também muito evidente a hibridização da techné com a aisthesis ${ }^{9}$, com riscos paralelos de conversão de toda vida em emoção controlável" (idem).

Quando falamos em estéticas midiáticas e narrativas de consumo, percebemos uma nova ordem intelectiva do sensível, de raízes audiovisuais e tecnológicas profundas. Ela se instala formando um novo "sensorium", conforme percebia Walter Benjamin (1996) na emergência da modernidade.

Rose de Melo Rocha fala que o consumo implica a consideração das interfaces entre cena tecnomidiática, cultura das mídias e culturas do consumo. E ele agora será apreendido como um processo que ultrapassa o plano estrito da posse e da apropriação de objetos, sendo a própria leitura crítica e os debates sobre as materialidades do valor de uso de tais objetos que nos ensinaram os sentidos dessa amplificação. Não se trata aqui de discutir sobre os meandros atinentes às dinâmicas de consumo cultural. Na verdade, trata-se de uma atenção maior ao entrelaçamento definitivo entre materialidades e produção simbólica (ROCHA in ROCHA; CASAQUI, 2012, p. 25).

A pesquisadora continua alertando para o fato de que "consumir hoje, é consumir cultura midiaticamente mediada, digitalmente interligada, imaginariamente compartilhada, imageticamente realizada" (idem, 2009, p. 269). Ainda aponta sobre as relações entre magia e capitalismo utilizando o antropólogo Everardo Rocha, que visualizou tais relações como um novo totemismo, semelhante a uma ritualização mística:

\footnotetext{
${ }^{9}$ Faculdade de sentir, compreensão pelos sentidos, percepção totalizante.
} 
A publicidade junta tudo magicamente. Na sua linguagem, um produto vira uma loura, o cigarro vira saúde e esporte, o apartamento vira a família feliz, o carro vira um fim de festa (...) na praia, a bebida vira o amor, etc, etc., tudo isto, tal como no totemismo, classificando o lado da produção com o do consumo. E colocando esta lógica da reciprocidade e da aliança, colocando o tempo em suspensão, bem no centro do nosso sistema social (ROCHA, 2010, p. 136).

Busca-se o diálogo de tais relações com a teatralização midiática referida no estudo deste artigo e seus meandros afetivos, sensíveis e suas abordagens tecnofísicas e simbólicas de interação com o público. Isto sutilmente agiliza despretensiosamente o consumo de informações, produtos ou qualquer outro tipo de objeto simbólico atrelado a um interesse maior de domínio, porém, com a máscara de atendente das necessidades e sonhos das massas. "O consumo (...) tornou-se o consumo de uma lógica, e esta lógica associa-se à proposição de uma experiência, no caso a de ser capaz de portar um determinado estado de espírito midiaticamente agenciado" (ROCHA in ROCHA; CASAQUI, 2012, p. 26-27).

Ressalto aqui que não é a intenção deste estudo abordar questões como consumo para felicidade, crise da felicidade na cultura de massa, dentre outros assuntos desse gênero. Visa-se aqui explicitar os pontos técnicos da teatralização que são utilizados pelas mídias na proporção de seus interesses para produção de reportagens, enunciados, textos, discursos e informações simbólicas produtoras de sentidos à margem da profundidade da aisthesis, e, portanto, da reflexividade crítica para transformação do sujeito. Nada é o que parece ser, principalmente no campo midiático.

O universo do jornalismo é um campo, mas que está sob a pressão do campo econômico por intermédio do índice de audiência. E esse campo muito heterônomo, muito fortemente sujeito às pressões comerciais, exerce, ele próprio, uma pressão sobre todos os outros campos, enquanto estrutura. Esse efeito estrutural, objetivo, anônimo, invisível, nada tem a ver com o que se vê diretamente (BOURDIEU, 1997, p. 77).

Adotando a necessidade de uma extensão desse estudo, faz-se necessário apontar o caminho a seguir para futuras pesquisas sob a luz crítica da comunicação e suas sinuosidades discursivas. Aponta-se aqui a colocação de Muniz Sodré em seu livro $A$ Ciência do Comum:

\footnotetext{
(...) os seres humanos são comunicantes, não porque falam (atributo consequente ao sistema linguístico), mas porque se relacionam ou organizam mediações simbólicas - de modo consciente ou inconsciente - em função de um comum a ser partilhado. No âmbito radical da comunicação, essas mediações não se reduzem à lógica sintática ou semântica dos signos, porque são transverbais, oscilantes entre mecanismos inconscientes, palavras, imagens e afecções corporais (SODRÉ, 2014, p. 9).
}

Aí está o cerne principal da teatralização midiática, componente principal do drama na mídia: a linguagem e a interação das relações somadas aos recursos cênicos do teatro, principalmente e mecanicamente no que concerne à voz do encenador, construindo, então, as mediações simbólicas do jogo midiático como um condutor mútuo dos atores sociais. 
ALTHUSSER, Louis. Aparelhos ideológicos de Estado. $7^{\text {a }}$ ed. Rio de Janeiro: Graal, 1998.

APPIAH, Kwame Anthony. Na casa de meu pai: a África na filosofia da cultura. Rio de Janeiro: Contraponto, 1997.

BAHKTIN, Mikhail Mikhailovich. Marxismo e a Filosofia da Linguagem. São Paulo: Hucitec, 1987. . A estética da criação verbal. São Paulo. Ed. WMF Martins Fontes, 2010.

BARCIA, J. Carlo. Ritual de la danza em el País Vasco. Revista de Dialectologia y Tradiciones Populares, tomo XX, xadernos $1^{\circ}$ e $2^{\circ}, 1964$.

BENJAMIN, Walter. Magia e Técnica, Arte e Política: ensaios sobre literatura e história da cultura. Obras Escolhidas, vol 1. São Paulo: Brasiliense, 1996.

BHABHA, Homi. O Local da Cultura. Belo Horizonte: Ed. UFMG, 1998.

BOURDIEU, Pierre. A economia das trocas simbólicas. São Paulo: Perspectiva, 2007a.

. A Distinção: crítica social do julgamento. São Paulo: Edusp; Porto Alegre: Zouk, 2007b.

Sobre a televisão. Rio de Janeiro. Ed. Zahar, 1997.

BURKE, Peter; BRIGGS, Asa. Uma história social da mídia: de Gutenberg à internet. Rio de Janeiro: Zahar, 2006.

CANCLINI, Nestor Garcia. Diferentes, desiguais e desconectados. Rio de Janeiro: Ed. UFRJ, 2007.

DEBORD, Guy. A sociedade do espetáculo. Rio de Janeiro: Contraponto, 1997.

DUARTE, Maurício; LOPES, Fernanda. Problemas Teóricos da Comunicação. Rio de Janeiro:

UFRJ/ECO, 2015

FOUCAULT, Michel. Microfísica do Poder. Rio de Janeiro: Edições Graal, 1979.

. A ordem do discurso. São Paulo: Ed. Loyola, 2004.

FREUND, Julien. A sociologia de Max Weber. Rio de Janeiro: Ed. Forense, 2010.

GEERTZ, Clifford. O saber local: novos ensaios em antropologia interpretativa. Petrópolis, RJ: Vozes, 2009.

. A Interpretação das Culturas. Rio de Janeiro: LTC, 2008.

GIDDENS, Anthony. Modernidade e identidade. Rio de Janeiro: Zahar, 2002.

GRAMSCI, Antônio. Cadernos do cárcere: Os intelectuais. O princípio educativo. Jornalismo. Vol 2. Rio de Janeiro: Civilização Brasileira, 2001.

HOBSBAWM, Eric. A Era dos Impérios: 1875-1914. São Paulo: Paz e Terra, 1987.

. A Era do Capital: 1848-1875. São Paulo: Paz e Terra, 1977.

JAEGER, Werner Wilhelm. Paidéia: a formação do homem grego. São Paulo: Martins Fontes, 1995.

KOSOVSKI, Ricardo. Guy Debord e a Sociedade do espetáculo - a imagem como mediadora da performance social. Rio de Janeiro: O Percevejo, 2004.

.Comunicação, Teatralidade e Realidade. Rio de Janeiro: Ed. UFRJ, 2002.

LUKÁCS, Georg. Arte e sociedade. Rio de Janeiro: Ed. UFRJ, 2009.

MATTELART, Michèle. História das Teorias da Comunicação. São Paulo: Ed. Loyola, 1999.

MORAES, Ricardo. Do Teatro na Comunidade ao Teatro Comunitário: comunicação e construção identitária do sujeito na resistência coletiva. VII ENECULT - Encontro de Estudos Multidisciplinares em Cultura. Universidade Federal da Bahia/UFBA, agosto de 2011.

ROCHA, Everardo. Magia e Capitalismo. São Paulo: Brasiliense, 2010.

ROCHA, Rose de Melo. CASAQUI, Wander. Estéticas midiáticas e narrativas de consumo. Porto Alegre: Sulina, 2012.

SAUSSURE, Ferdinand. Curso de Lingüística Geral. São Paulo: Cultrix, 1995.

SIMÕES, Denis Gerson. Peter Burke, uma história social da mídia e do conhecimento. EPICT - Revista internacional de economia política da informação da comunicação e da cultural. Sergipe, vol XIII, $\mathrm{n}^{\circ}$ 3 , set. - dez./2010. 
SODRÉ, Muniz. A ciência do comum: notas para o método comunicacional. Petrópolis, RJ: Vozes, 2014.

. As estratégias sensíveis: afeto, mídia e política. Petrópolis, RJ: Vozes, 2006.

Vozes, 2002.

Antropológica do Espelho: uma teoria da Comunicação Linear e em Rede. Petrópolis, RJ:

VAZ, Paulo. Comunicação e História do Pensamento I - Da confissão ao testemunho: identificação, normalidade e discurso autobiográfico. Rio de Janeiro: UFRJ/ECO, 2014.

\section{Recebido em 05/10/2015. Aprovado em 12/10/2015.}

Title: Mediatic drama as discourse of truth: seduction and affect for the consumption of simbolic information

Abstract: The present essay aims to investigate the simbolic discourse, under a mediatic drama point of view, as an appropriated dramatization by communication channels, in which the use of image is similar to the pictorical aspects of the theatral scene. Such dramatization avoids the essential researchs of theatrical comunication, leading to a detour from the universalized discourse; a strong mediatic element of common sense in the relations and social organizations.

Keywords: Media. Communication. Drama. Dramatization. Simbolic discourse. 